\title{
Three Dimensional Radiation Treatment Planning for the Treatment of Nasopharyngeal Carcinoma
}

\author{
Manav Rakshak, Vivek Kaushal, Bhagbat Prasad Das
}

\begin{abstract}
Abstrak
Telah dilakukan analisa terhadap perencanaan radiasi secara 2 dan 3 dimensi $(2 D$ dan $3 D)$ yang dibuat dengan bantuan komputer untuk karsinoma nasofaring. Perbandingan penilaian ditinjau berdasarkan pengamatan pada pancaran sinar pemandu (beam's eye view), displai multi-planar, jumlah kumulatif dan perbedaan histogram dosis-volume. Pada penelitian ini diajukan sebuah parameter baru, yaitu perbedaan in-homogenitas. Nilai perbedaan inhomogenitas didefinisikan sebagai perbedaan antara dosis radiasi maksimum dan minimum untuk menyinari sedikitnya $5 \%$ dari volume darah target radiasi. Apabila dosis penyinaran total yang dibutuhkan dinyatakan sebagai gradasi maksimum, maka nilai parameter terkecil menunjukkan homogenitas dosis radiasi pada tumor yang lebih baik. Hasil analisa menunjukkan bahwa perencanaan radiasi 3D mampu menyinari $64 \%$ volume daerah target dengan dosis radiasi setinggi $95 \%$ dari dosis yang ditetapkan. Sedangkan perencanaan $2 D$ hanya memberi penyinaran pada daerah seluas $32 \%$ dari volume target. Selanjutnya $95 \%$ volume target klinis mendapat radiasi sebesar $88 \%$. (3D) dan $82 \%$ pada $2 D$. Parameter perbedaan inhomogenitas menunjukkan nilai yang lebih rendah untuk perencanaan radiasi $3 D$ dibandingkan dengan $2 D$, baik untuk faktor volume daerah target maupun untuk volume total tumor. Analisa parameter-parameter diatas menunjukkan adanya peningkatan rerata dosis tumor dan homogenitas dosis tumor pada perencanaan $3 D$ dibandingkan dengan $2 D$. Dengan perencanaan $3 D$ dan $2 D$, maka daerah jaringan normal yang terkena radiasi seperti kelenjar parotis, bola mata, sumsum tulang belakang dan rahang bawah dapat dihitung.
\end{abstract}

\begin{abstract}
Three dimensional $(3 D)$ and two dimensional $(2 D)$ computerised radiation treatment planning in the treatment of nasopharyngeal carcinoma (N.P.C.) have been analysed using beam's eye view, multiplanar displays, cumulative and differential dose volume histograms and a new parameter called inhomogeneity-difference(ID). Inhomogeneity difference is a value defined as the difference between the of grid maximum. Smaller doses to a volume of no less than 5\% of the target volume, when all doses are expressed as the percentage in $3 D$ as compared to the dose to $95 \%$ of clinical target volume was $88 \%$ as come receiving $95 \%$ of the dose was $64 \%$ as compared to $32 \%$ of grid maximum; compared to $2 D$ plans for both of clinical target volume and to $82 \%$ of grid maximum. ID had lower values for the $3 D$ plans as mean tumour dose and the gross tumour volume. These parameters revealed the increasing of doses of the normal tissues such as parotid geity in the $3 D$ than the to $2 D$ computerised radiation plans. In this planning, the absorbed

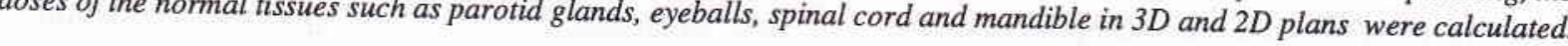

Keywords: Radiotherapy-planning, Computer-assisted

\section{INTRODUCTION}

Clinically and radiologically, it is difficult to assess the margin of a nasopharyngeal carcinoma (NPC), so does the surgical resection of a NPC with an acceptable margin. Radiation therapy is the treatment of choice for NPC. Increased tumour control can be achieved by

PT.B.D.S. Post-Graduate Institute of Medical Sciences, Rohtak, Haryana, India. a thorough evaluation of extension of the primary and using large fields to cover the suspected tumour and by delivering doses of at least $70 \mathrm{~Gy}$ in 35 fractions over 7 weeks. This necessitates careful and meticulous radiation treatment planning. A decrease in frequency of inadequate coverage of the nasopharynx has been accomplished with a growing sophistication of treatment techniques over the last decade. ${ }^{1}$ The $3 \mathrm{D}$ radiation planning is a recent technique in the Asian countries included Indonesia. This present study is used to evaluate the role of $3 \mathrm{D}$ radiation planning in improving the tumour coverage and the normal tissue sparing in computed tomography based on 3D and 2D radiation planning. 


\section{MATERIALS AND METHODS}

A previously untreated patient with histological finding of squamous cell carcinoma of the nasopharynx was conducted in this study. The extension of the disease was determined by panendoscopy including nasopharyngoscopy and radiological investigations i.e. soft tissue X-ray examination of the neck , X-ray examination of the paranasal sinuses, X-ray examination of the base of the skull and CT scan in the head and neck region. The patient had a growth in the nasopharynx with the extension to the right nasal cavity, oropharynx, right tonsil, base of the skull in the region of the middle cranial fossa. AJCC 1992 TNM staging system was used and the disease was in stage IV $\left(\mathrm{T}_{4} \mathrm{~N}_{0} \mathrm{M}_{0}\right)$.

Contiguous diagnostic CT slices of $10 \mathrm{~mm}$ thickness were obtained in the treatment position from the vertex of the skull to the angle of Louis on Shimadzu SCT$3000 \mathrm{TF}$ scanner. These slices were transferred to Theraplan 500 radiation treatment planning computer using 8 inch floppy discs. Two major target volumes were outlined on all the CT slices.

(a) Gross tumour volume (GTV). GTV included the primary tumour observed clinically or radiologically with the margin of one centimetre.

(b) Clinical target volume (CTV). CTV included the gross primary tumour, the possibility of microscopic extension and clinical involvement of the lymph nodes.

In this study, the GTV included the nasopharynx, ethmoid cells, sphenoid sinus, basisphenoid, base of skull, nasal cavity, maxillary antrum, pharyngeal wall (lateral and posterior) and lower pole of the tonsils. In addition to these structures, the CTV included the retropharyngeal nodes, mastoid nodes, upper cervical and posterior cervical nodes. The critical normal structures i.e. spinal cord, eyeballs, parotid glands, mandible etc. were outlined on all CT slices as appropriate.

The treatment plans were grouped into two types: (a) Two dimensional (2D) planning: Beam arrangements were selected on the basis of restricted information in the CT slice passing through the centre of GTV. The beam arrangement that gave the best target volume coverage and maximum normal tissue sparing in central slice was selected.

(b) Three dimensional (3D) planning: This treatment plan was based on the geometric information contained on all slices. CTV and GTV coverage and critical normal tissue sparing were done on the basis of 3D information available for both target volumes and appropriate normal tissues on all of the slices.

All plans were normalised to grid maximum and designed for $70 \mathrm{~Gy}$ in 35 fractions in 7 weeks for GTV. Plan evaluation tools consisted of beam's eye view, multiplanar displays, cumulative and differential dose volume histograms. ICRU reference dose was also reported for each plan. ICRU reference point was taken for this study, as the point at which central axes of all beams was met. Statistical parameters like V95, D95 and $\mathrm{DO}^{3,4}$ were analysed. V95, is defined as the target volume receiving $95 \%$ of the dose; $\mathrm{D} 95$, as the dose to $95 \%$ of the target volume; DO5 as the minimum dose that $5 \%$ of the volume received. We have defined another parameter, relevant to the target volume dose homogeneity i.e. inhomogeneity difference that means a numerical value defined as the difference between the maximum and the minimum doses to a volume of no less than $5 \%$ of the target volume when all doses are expressed as percentage of grid maximum. Lesser value of this parameter means better tumour dose homogeneity.

\section{RESULTS}

A $2 \mathrm{D}$ radiation treatment planning was done using information from a single slice. A single direct anterior beam with two parallel opposed wedged lateral portals was used for irradiating the GTV adequately. Minimum dose envelop used in this study was $90 \%$ isodose line. All three beams were coplanar. When $3 \mathrm{D}$ radiation treatment planning was performed, the direct anterior beam was found to provide inadequate coverage of the GTV in slices, adjacent to the central slice. Lateral beams were also modified by rubberband software in the beam's eye view option to conform the shape and size of the GTV in its three dimensions. Beam's eye view is a feature in which the patient is viewed as if the observer's eye is placed at the source of the radiation beam. CT information on all slices is virtually simulated to give better idea about radiation field placement over the target volume and its relationship with the critical normal structures and the patient's contour. This information also shows the areas of the tumour not being covered by the beams individually. Beams were then modified using this information. Beam's eye view was also used for placing blocks and designing irregular beams accurately for the 3D plans. Figure 1 shows the beam's eye view of the radiation field in relation to GTV, spinal cord and brain for the right lateral wedged beam which was used in 3D radiation treatment planning. Changes were 
required, while $3 \mathrm{D}$ planning were done in beam placement, field size and shape, beam weightage and collimator angle.

Table 1 shows the values of three parameters for CTV and GTV for 3D and 2D plans signifying better target volume coverage in the 3D plan. The dose at the ICRU reference point was $94 \%$ as compared to $96 \%$ in 2D versus 3D plan. Inhomogeneity difference(ID), which is indicator of tumour dose homogeneity, is smaller in 3D plan; that means 3D plan has better tumour dose homogeneity.

Table 1. Dose volume histogram analysis

\begin{tabular}{lccccc}
\hline Target Volume & Plan & V95 & D95 & D05 & ID \\
\hline CTV & 2D & 32 & 82 & 82 & 16 \\
& 3D & 64 & 88 & 88 & 10 \\
GTV & 2D & 20 & 91 & 91 & 5 \\
& 3D & 66 & 96 & 94 & 3 \\
\hline
\end{tabular}

All values are expressed as percentage of grid maximum. CTV: Clinical target volume; GTV: gross target volume; V95: volume getting $95 \%$ of dose; D95: dose to $95 \%$ of volume; D05: minimum dose to $5 \%$ of volume;

ID: inhomogeneity difference.
Normal tissue doses were studied as doses to one-third (D1/3) ; two-third ( D2/3) and whole (D3/3) of the normal tissue volume contained in all CT slices. ${ }^{5}$ Table 2 shows normal tissue absorbed doses for critical normal stuctures lying in close proximity to the target volumes, as computed from the cumulative dose volume histograms.

Table 2. Normal tissue absorbed doses in 2D/3D plans

\begin{tabular}{lcccccc}
\hline Organ & $\begin{array}{c}\text { D1/3 } \\
\text { 2D }\end{array}$ & $\begin{array}{c}\text { (Gy) } \\
\text { 3D }\end{array}$ & $\begin{array}{c}\text { D2/3 } \\
\text { 2D }\end{array}$ & $\begin{array}{c}\text { (Gy) } \\
\text { 3D }\end{array}$ & $\begin{array}{c}\text { D3/3 } \\
\text { 2D }\end{array}$ & $\begin{array}{c}\text { (Gy) } \\
\text { 3D }\end{array}$ \\
\hline Spinalcord & 25 & 34 & 17 & 17 & 1.4 & 3 \\
Right parotid* & 61 & 64 & 55 & 55 & 28 & 28 \\
Left parotid* & 53 & 58 & 38 & 48 & 17 & 24 \\
Mandible & 65 & 62 & 55 & 49 & 27 & 27 \\
Right eye* & 41 & 10 & 34 & 4 & 21 & 1.4 \\
Left eye* & 42 & 38 & 41 & 29 & 14 & 8 \\
\hline
\end{tabular}

* Less than $50 \%$ of volume does not make a significant change. $\mathrm{D} 1 / 3=$ dose to one-third, $\mathrm{D} 2 / 3=$ dose to two-third and D3/3 = dose to whole of the normal organ.

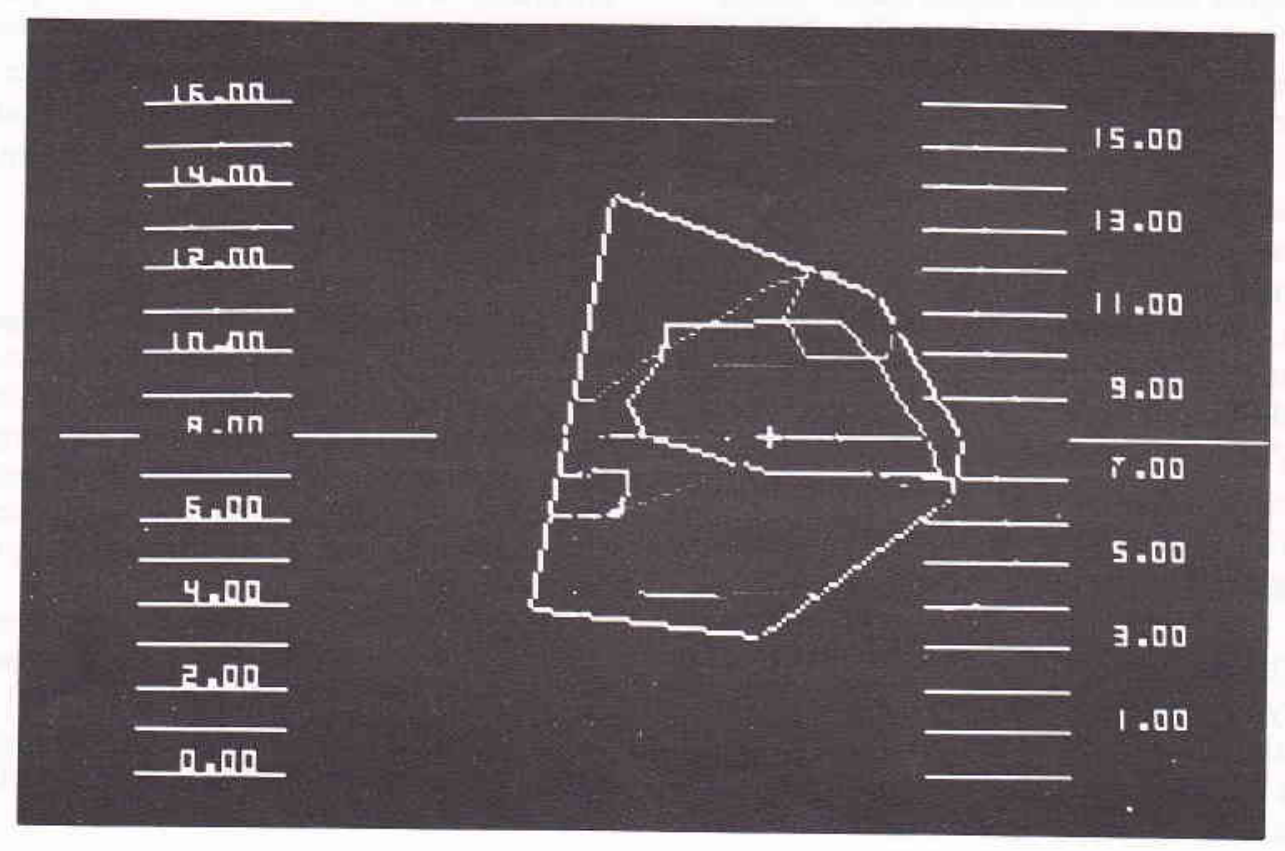

Figure 1. Beam's eye view: Right lateral wedged beam in $3 D$ planning of irregularly shaped radiation field (white) is shown in relation to the (light blue), spinal cord (red), brain (pink). 


\section{DISCUSSION}

Once the dose calculation was done in three dimensions, isodose distribution information was displayed on all CT slices of the patient and also for many planes i.e. axial, sagittal, coronal etc. by multiplanar reconstruction. This demonstrated tumour coverage and normal tissue sparing at any number of planes for viewing isodose distribution at each level.

For evaluation of optimal beam arrangement, cumulative as well as differential dose volume histograms were used. They illustrate the dose that various organs receive. A differential dose volume histogram displays the distribution of dose received by each volume unit of the specified organ. Cumulative dose volume histograms were found very useful for assessing normal tissue absorbed doses as doses to the one-third, twothird and whole of the normal tissue volume contained on all the CT slices. However, these histograms do not give any idea of spatial distribution of doses, for which multiplanar isodose distributions were helpful.

Various parameters available for dose volume distribution analysis are V95, D95, D05 and inhomogeneity difference. They indicated target volume coverage. The V95 is the volume receiving $95 \%$ of dose. The D95 is the dose to $95 \%$ of volume. They indicated the mean tumour dose. Higher values mean higher mean tumour dose. The D05 is the minimum dose to $5 \%$ of target volume and is related to chances of tumour recurrence. Lower value of the D05 means more chances of tumour recurrence. In our study, V95, D95 and D05 are greater in $3 \mathrm{D}$ plans. Inhomogeneity difference is the numerical value defined as the difference between the maximum and the minimum doses to a volume of no less than $5 \%$ when all doses are expressed as percentage of grid maximum. It indicates the tumour dose homogeneity. Lesser is the difference, better is the tumour dose homogeneity. Values in Table 1 indicate that $3 \mathrm{D}$ planning allowed increasing mean tumour dose (higher V95 and D95 in 3D plan) with better dose homogeneity (lower inhomogeneity difference values in 3D plan).

For a length of 0.1 metre of spinal cord, $50 \mathrm{~Gy}$ produces $50 \%$ probability of myelitis within 5 years after treatment. ${ }^{5}$ In our study, a dose of $17 \mathrm{~Gy}$ was given to the spinal cord. For the parotid glands, 32 Gy produces $5 \%$ probability of xerostomia at 5 years after treatment. ${ }^{5}$
In our study which has employed cobalt-60 as the radiation source, doses to parotid glands have exceeded their tolerance limits. Chances of pathologic fracture / osteoradionecrosis of the mandible which would occur within 5 years from the treatment are less than $5 \%$, since the tolerance doses of 60 Gy have not been exceeded. For eyeballs (retina), with blindness as the end point, tolerance dose is $45 \mathrm{~Gy} .{ }^{5}$ These doses have not been exceeded in any plan.

\section{CONCLUSION}

The parameters considered for dose volume distribution analysis were found to be beneficial in computerised radiation treatment plan evaluation. According to the dose volume histogram, a better coverage of the target volumes by three dimensional radiation treatment planning is recorded while the information from all slices was utilized. We have demonstrated that it is possible to increase the mean tumour dose and improve the tumour dose homogeneity by using three dimensional planning technique for the treatment of the NPC as compared to two dimensional planning. We have found that the dose volume histogram based on the $3 \mathrm{D}$ radiation treatment plan analysis can be carried out satisfactorily by using various statistical parameters. Inhomogeneity difference was found to be a unique parameter, that allowed evaluation of the target volume dose homogeneity and is hoped to find wider application. The doses of the spinal cord, mandible and eyeballs did not exceed the tolerance limits in our study.

\section{REFERENCES}

1. Marks JE, Bedwinek JM, Lee F et al. Dose response analysis for nasopharyngeal carcinoma. Cancer 1982;50:1042.

2. International Commission on Radiation Units and Measurements, Prescribing, Recording and Reporting Photon Beam Therapy. Bethesda (MD): ICRU;1992;Report no.50.

3. Coia L, Galvin J, Sontag M et al. Three dimensional photon treatment planning in carcinoma of the larynx. Int $J$ Radiat Oncol Biol Phys 1991;21:182-92.

4. Kutcher GJ, Fuks Z, Brenner H et al. Three dimensional photon treatment planning for carcinoma of the nasopharynx. Int J Radiat Oncol Biol Phys 1991;21:169-82.

5. Emami B, Lyman J, Brown A et al. Tolerance of normal tissue to therapeutic irradiation. Int J Radiat Oncol Biol Phys 1991;21:109-22. 